Original Research Article

\title{
Comparative analysis of epinastine vs olopatadine eye drops in moderate allergic conjunctivitis patients
}

\author{
Preet Sood*, Manmohan Bhanot, Narinder Singh, Rahat Kumar
}

Department of Pharmacology, Sri Guru Ram Das Institute of Medical Sciences and Research Vallah, Amritsar, Punjab, India

Received: 13 August 2016 Accepted: 15 September 2016

*Correspondence to:

Dr. Preet Sood,

Email: preetsood@yahoo.co.in

Copyright: (C) the author(s), publisher and licensee Medip Academy. This is an openaccess article distributed under the terms of the Creative Commons Attribution NonCommercial License, which permits unrestricted noncommercial use, distribution, and reproduction in any medium, provided the original work is properly cited.

\begin{abstract}
Background: Allergic conjunctivitis is a perennial ocular allergic disease. It is the inflammatory response of the conjunctiva to allergens such as pollen, animal dander, and other environmental allergens. The treatment consists of avoidance of the offending antigen, topical decongestants, antihistamines, mast cell stabilizers, non steroidal anti-inflammatory drugs and corticosteroids.

Olopatadine hydrochloride $0.1 \%$ ophthalmic solution (Patanol) and Epinastine hydrochloride $0.05 \%$ ophthalmic solution (Elestat) are two topical ant allergic agents.
\end{abstract}

Methods: After taking institutional ethics committee approval, total $n=62(33$, 29) patients were enrolled. Patients were randomized and divided into two study groups (1-olopatadine, 2-epinastine). After prescribing the drug therapy (day 1), patients were asked to visit at 3,7,15 day and at 1month. At every visit, slit lamp examination was done. Changes in all sign/symptoms were recorded. For the statistical testing of the data Chi-square test is used to find the association of variable. Mann Whitney $-\mathrm{u}$ test is applied for the statistically analysing the two group.

Results: Both the study drugs found to be equally efficacious except at few points. Only statistically marked difference was observed in papillary hyperaemia $(p<0.001)$ at 1 month where olopatadine found to be highly effective.

Conclusions: Both drugs are found to be equally effective in moderate allergic conjunctivitis. Olopatadine is found effective in palpebral hyperaemia so it can be recommended in only moderate to severe conjunctivitis.

Keywords: Allergic conjunctivitis, Anti histaminic, Epinastine, Mast cell stabilizers, Olopatadine

\section{INTRODUCTION}

Allergic conjunctivitis is a perennial ocular allergic disease. It is the inflammatory response of the conjunctiva to allergens such as pollen, animal dander, and other environmental allergens. Allergic conjunctivitis comprises of itching, watering, photophobia, lid oedema, conjunctival hyperaemia and palpebral hypertrophy. Only about $10 \%$ of individuals with allergic conjunctivitis seek medical attention, and the entity is often underdiagnosed. Redness and itching are the most consistent symptoms. Seasonal allergic conjunctivitis comprises $90 \%$ of all the allergic conjunctivitis cases.
Treatment consists of avoidance of the offending antigen anduse of saline solution or artificial tears to physically dilute and remove the allergens. Topical decongestants, antihistamines, mast cell stabilizers, nonsteroidal antiinflammatory drugs, and corticosteroids may be indicated.

Olopatadine hydrochloride $0.1 \%$ ophthalmic solution (Pataday) and Epinastine hydrochloride $0.05 \%$ ophthalmic solution (Epina) are two topical ant allergic agents. Both drugs are indicated for the treatment of the signs and symptoms of allergic conjunctivitis that include itching, redness, tearing, lid swelling, and chemosis. ${ }^{1}$ 
Cost of the drugs:

- Epinastine (Epina) - 0.05\% (5ml) Bid Rs.90 (180),

- $\quad$ Olopatadine (Pataday) - 0.2\% (2.5ml) Od Rs.250

\section{METHODS}

A single blind randomized study was conducted to compare the efficacy and safety of two anti allergic and mast cell stabilizers i.e. Olopatadine and Epinastine eye drops in moderate allergic conjunctivitis. After taking institutional ethics committee approval, total $n=62(33$, 29) patients were enrolled. Randomization was done by computer generated technique using software statemata. After randomization the patients were divided into two study groups (1-olopatadine, 2-epinastine). Informed written consent was obtained from the patient or the attendant. Two type of prescription were structured. After the selection of the patient from the routine OPD, patient was given already structured prescription. Prescription was given by an attendant who was having the randomized key with him.

After prescribing the drug therapy (day 1), patients were asked to visit at 3,7,15 day and at 1 month. At every visit, slit lamp examination was done. Changes in all sign/symptoms were recorded. The OAI was calculated as a composite score of 6 signs and symptoms of allergic conjunctivitis to assess global severity. For the statistical testing of the data- Chi-square test is used to find the association of variable. Mann Whitney u test is applied for the statistically analysing the two groups. A p-value of $<0.05$ was considered as the threshold for determining statistical significance.

\section{RESULTS}

In the study total 100 patients of allergic conjunctivitis were screened, Total 62patients completed the study $($ Olopatadine $=33$, Epinastine $=29)$.

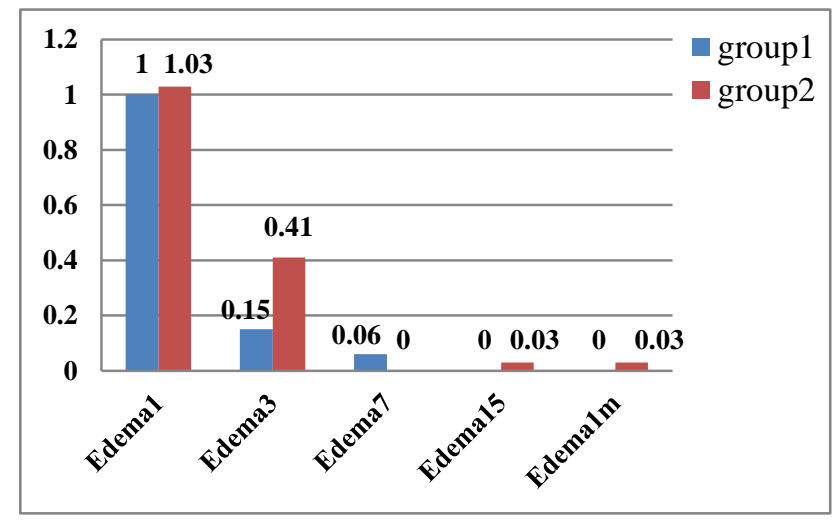

Figure 1: Lid edema.

Patients were examined with slit lamp in all visits by the investigator. All the parameters are depicted in bar charts.
Both the study drugs found to be equally efficacious except at few points. Only statistically marked difference was observed in papillary hyperaemia $(p=0.001)$ at 1 month where olopatadine found to be highly effective.

At other points, Olopatadine found to be significantly more effective for watering and photophobia at 7day $(p=0.017)$. Epinastine is found better for edema at 3 days $(\mathrm{p}=0.022)$.

There were no adverse events for either treatment.

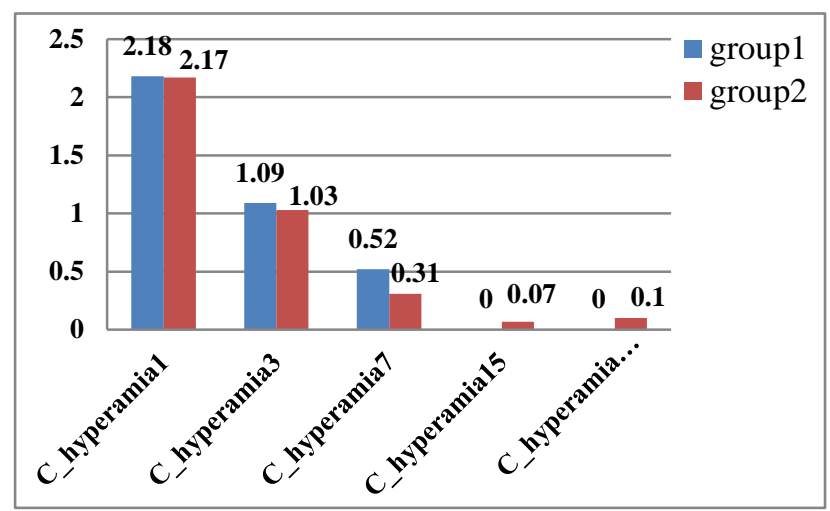

Figure 2: Conjuctival hyperemia.

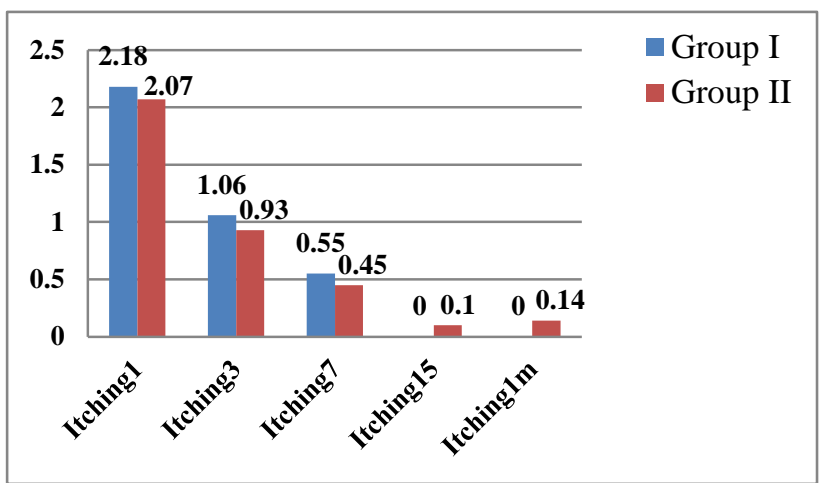

Figure 3: Itching.

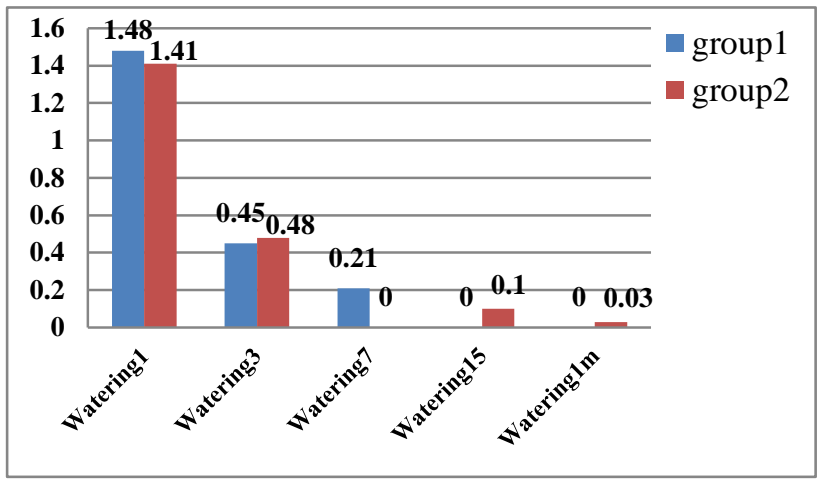

Figure 4: Watering. 


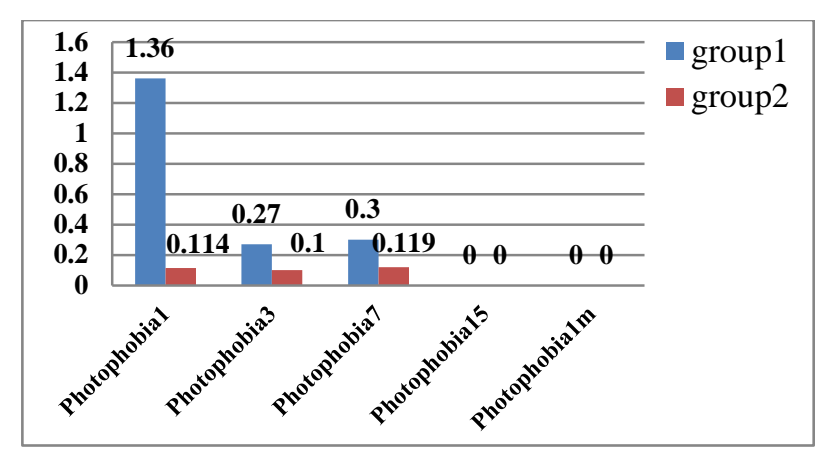

Figure 5: Photophobia.

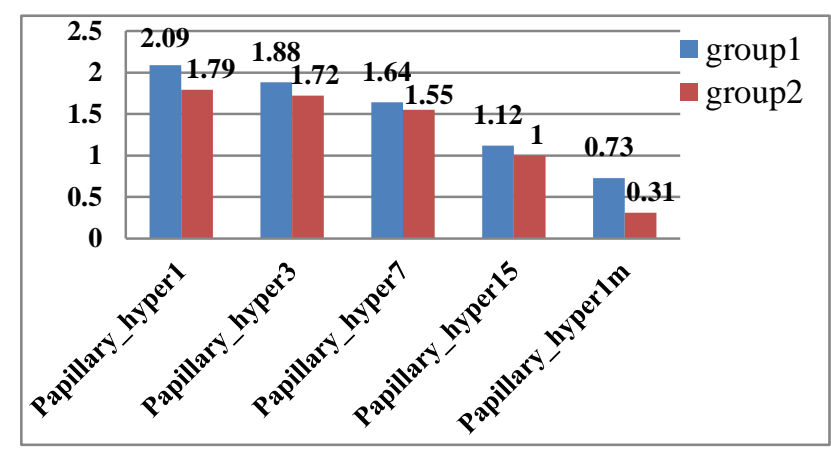

Figure 6: Papillary hypertrophy.

\section{DISCUSSION}

Anti allergic and mast cell stabilizers are the mainstay of treatment in allergic conjunctivitis. In the previous studies. ${ }^{1,2,4,5}$ Olopatadine is found superior than epinastine in allergen Challenge models. It is found superior in controlling both subjective (itching) as well as objective (redness, chemosis) sign and symptoms. ${ }^{3}$

But in our study only effect on papillary hypertrophy at 1 month is statistically significant. In real life treatment starts after the release of inflammatory substances while in allergen models the study drugs are instilled prophylactically. ${ }^{1,3}$ Mast cell stabilizers works best when used before the exposure. Once degranulation is there effect on mast cells is compromised. In allergic conjunctivitis olopatadine and epinastine both expresses its anti allergic action, mast cell stabilizer action is may or may not be expressed. Secondarily, in our study we examined the patient at 1, 3, 7 and 15 days intervals while in all postulated studies it was in minutes like 3,5 and 7 or 10,15 and 20 minutes. It is not practically possible in real life situation.

\section{CONCLUSION}

Olopatadine is marketed as a much efficacious drug in moderate allergic conjunctivitis patients.

But in our study, both drugs are found to be equally effective in moderate allergic conjunctivitis. Olopatadine is found effective in palpebral hyperaemia so it can be recommended in only moderate to severe conjunctivitis. For moderate allergic conjunctivitis Epinastine should be encouraged as being a cheap drug.

Funding: No funding sources Conflict of interest: None declared

Ethical approval: The study was approved by the Institutional Ethics Committee

\section{REFERENCES}

1. Lanier BQ, Finegold I, D'Arienzo P, Granet D, Epstein $\mathrm{AB}$, Ledgerwood GL. Clinical efficacy of olopatadine vs epinastine ophthalmic solution in the conjunctival allergen challenge model. Curr Med Res Opin. 2004 Aug;20(8):1227-33.

2. Ousler GW, Workman DA, Torkildsen GL. An openlabel, investigator-masked, crossover study of the ocular drying effects of two antihistamines, topical epinastine and systemic loratadine, inadult volunteers with seasonal allergic conjunctivitis. Clin Ther. 2007 Apr;29(4):611-612.

3. Bielory L. Allergic conjunctivitis: the evolution of therapeutic options. Allergy Asthma Proc. 2012;33(2):129-39.

4. Bielory L, Lien KW, Bigelsen S. Efficacy and tolerability of newer antihistamines in the treatment of allergic conjunctivitis. Drugs. 2005;65(2):215-28.

5. Abelson MB, Gomes P, Crampton HJ, Schiffman RM, Bradford RR. Efficacy and tolerability of ophthalmic epinastine assessed using the conjunctival antigen challenge model in patients with a history of allergic conjunctivitis. 2004.

6. Pradhan S, Abhishek K, Mah F. Epinastine: topical ophthalmic second generation antihistamine without significant systemic side effects. Expert Opin Drug Metab Toxicol. 2009 Sep;5(9):1135-4.

7. Bielory BP, O'Brien TP, Bielory L. Management of seasonal allergic conjunctivitis: guide to therapy. Acta Ophthalmol. 2012;90(5):399-407.

8. Owen CG, Shah A, Henshaw K. Topical treatments for seasonal allergic conjunctivitis: systematic review and meta-analysis of efficacy and effectiveness. Br J Gen Pract. 2004;54(503):451-6.

9. Yaylali V, Demirlenk I, Tatlipinar S. Comparative study of $0.1 \%$ olopatadine hydrochloride and $0.5 \%$ ketorolac tromethamineinthe treatment of seasonal allergic conjunctivitis. Acta Ophthalmol Scand. 2003;81(4):37882.

10. Donshik PC, Pearlman D, Pinnas J. Efficacy and safety of ketorolac tromethamine $0.5 \%$ and levocabastine $0.05 \%$ : a multi centre comparison in patients with seasonal allergic conjunctivitis. Adv Ther. 2000;17(2):94-102.

11. Rosario N, Bielory L. Epidemiology of allergic conjunctivitis. Curr Opin Allergy ClinImmunol. 2011;11(5):471-6.

Cite this article as: Sood P, Bhanot M, Singh N, Kumar R. Comparative analysis of epinastine vs olopatadine eye drops in moderate allergic conjunctivitis patients. Int J Basic Clin Pharmacol 2016;5:2449-51. 